\title{
EVALUATION OF CLIMATE SCENARIOS PROJECTIONS AND ASSOCIATED ERRORS IN A REGION IN ILLINOIS (USA) ACCORDING TO CMIP5 MODELS
}

\author{
RESENDE, Nicole Costa - nicole.resende@yahoo.com.br \\ Universidade de São Paulo/USP \\ MIRANDA, Jarbas Honorio - jhmirand@usp.br \\ Universidade de São Paulo/USP
}

\begin{abstract}
Observed data from different parts of the world shows that many natural systems are being affected by regional climate changes. Some models has been used as a tool to help studies to evaluate the impacts of climate changes in different sectors. However, this models has some errors due to the parametrization necessary and also due to the streamline equations in order to describe a chaotic system. This issue make essential to conduct research in order to verify the regions where these errors are more prominent. The aim of this research is evaluate the climate scenarios given by CMIP5 models by studying the associated errors of this modeling. Also, is described the climatology and the possible changes of climate and extreme events in the region according to different scenarios of projections. The model IPSL(CM5MR) was founded as the most accurate for the analyzed region, although the model presented tendency of underestimation of precipitation and average and maximum temperature between 1901 to 2005. Regarding to minimum temperature this models has tendency to overestimation. Regarding to the indexes of extreme events, we noticed that most of them showed good performance. The model shows tendency of increasing of precipitation and increase of occurrence of extreme events, mostly of accumulated precipitation in one and 5 days. Consecutive wet days also may increase. It is also noticed decreasing of number of frost days and icing day and increasing of number of summer days.
\end{abstract}

Keywords: climate modeling, extreme events, climate changes.

\section{AVALIAÇÃO DE PROJEÇÕES DE CENÁRIOS CLIMÁTICOS E ERROS ASSOCIADOS EM UMA REGIÃO NO ILLINOIS (EUA) DE ACORDO COM OS MODELOS CMIP5}

RESUMO: Os dados observados de diferentes partes do mundo mostram que muitos sistemas naturais estão sendo afetados pelas mudanças climáticas regionais. Modelos climáticos têm sido usados como uma ferramenta para ajudar estudos de avaliação dos impactos das mudanças climáticas em diferentes setores. No entanto, esses modelos têm alguns erros devido à parametrizações necessárias aos modelos e também devido à simplificação de equações para descrever um sistema caótico. Esta questão torna essencial a realização de pesquisas para verificar as regiões onde esses erros são mais proeminentes. O objetivo desta pesquisa é avaliar os cenários climáticos dados pelos modelos CMIP5, estudando os erros associados a estes modelos. Além disso, é descrita a climatologia e as possíveis mudanças de clima e eventos extremos na região de acordo com diferentes cenários de projeções. O modelo IPSL (CM5MR) foi descrito como o mais preciso para a região analisada, embora o modelo apresente tendência de sub estimativa da precipitação e temperaturas médias e máximas, entre 1901 e 2005. Em relação às temperaturas mínimas, esse modelo tende a superestimativa. Em relação aos índices de eventos extremos, percebemos que a maioria dos modelos apresentaram um bom desempenho. O modelo IPSL (CM5MR) mostra tendência de aumento da precipitação e aumento da ocorrência de eventos extremos, principalmente de precipitação acumulada em um e cinco dias. O número de dias consecutivos de chuva também tendem a aumentar. Também é notada a diminuição do número de dias frios e o aumento do número de dias quentes.

Palavras-chaves: modelagem climática, eventos extremos, mudanças climáticas. 


\section{INTRODUCTION}

Observed data from different parts of the world shows that many natural systems are being affected by regional climate changes. In 1988 was created the Intergovernmental Panel on Climate Change (IPCC) in order to study the issues of global climate changes. According to one of the IPCC's report (SOLOMON et al., 2007), in 20th century the earth experimented increase of average temperature around $0.65^{\circ} \mathrm{C}$, and this happened mostly in the 90 decade. Another report of IPCC (STOCKER et al., 2014) shows that data series from 1901 to 2012 indicates that almost the entire globe has experienced surface warming. The causes of this variations is still unknown and can be due to natural or anthropogenic activities, or the combination of both. Many researches have been looking for the cause of this changes, but there is still no agreement between them.

The effects of climate change is already noticed in different sectors. Expectation is that in the future these effects will be compounded. Due to the global warning in a near future is supposed to be more extreme climate scenarios with droughts, floods and heat waves occurring more often, and impacts as elevation of the ocean level and more often and extremes hurricanes can also be experimented with the melting glaciers (SALATI et al., 2004). Rosenzweig e Hillel (1998) indicates that the precipitation reduction could intensify further aquifer exploration for agriculture and place additional burdens on other surface and groundwater resources from non agricultural use. On other hand, the increase of potential evapotranspiration can intensify drought stress. Some research has been made about climate change in hydrological studies (GREEN et al., 2011) and changes in extreme events and precipitation patterns (NEW et al., 2001; Frich et al., 2002; Haylock et al., 2006; Kharin et al., 2013; KAZMIERCZAK et al., 2014).

In a research conducted by Kalnay e Cai (2003) the authors concluded that the temperature may rise up to $0.088^{\circ} \mathrm{C}$ per decade. This values is near to the optimistic scenario presented in the IPCC report. The magnitude of this forecast is still uncertain because there is some doubts about the exchange process of heat, carbon and radiation between the various sectors of the Earth system. The rise in temperature can increases the air capacity of retaining water vapor and can cause a higher water demand. In response to these changes, plant ecosystems may increase the biodiversity or suffer negative influences. According to Thomas et al. (2004), with the elevation of temperature 18 species are threatened by extinction by the year of 2050, considering the most optimistic scenario.

The IPCC (AR5) report also indicate the occurrence of extreme events, concluding that it is possible that the number of warm days and also the number of cold nights has increased in a global scale. Also it is probable that the frequency of warm waves had increase in most part of Europe, Asia and Australia. There is also indication of increasing of frequency and intensity of events of intense precipitation in North America and Europe. Some climate models can approach the average values of the variable but has difficulty to forecast extreme events. This happens mostly when a long term integration is made. This is an issue considering that in general the extreme events can have bigger impact than average values. 
A research of Kharin et al. (2013) used an ensemble of models to study twenty-year temperature and precipitation extremes and their projected future changes. The simulate late 20th century extremes and conclude that the warm extremes was represented reasonably well, compared to estimates from reanalyses. Also, the model discrepancies in simulating cold extremes are generally larger than those for warm extremes. Considering the precipitation extremes simulation they achieve be plausible in the extra-tropics but uncertainty in extreme precipitation in the tropics and subtropics remains very large, both in the models and the observationally-constrained data sets.

Groisman et al. (2005) and Marengo e Valverde (2007) identified in the subtropical part of Brazil a large systematic increase in rainfall since the 1950s and, in southeastern of Brazil they found an increase in the frequency of extreme rainfall events. Carvalho et al. (2004) found that extreme rainfall events exhibit inter-annual variability linked to El Nino and La Nina and intraseasonal variations associated with the activity of South Atlantic Convergence Zone (SACZ) and South America Low Level Jet, on the state of Sao Paulo. Nobre et al., (2010) showed that heavy rains have become more frequent in Sao Paulo. Also daily rainfall totals exceeding 50 millimeters, which occurred with an average frequency of 9 times every 10 years in the 1930s, began to occur with a frequency of 40 times in the 2000s.

Frich et al. (2002) using observed data showed an increasing trend in the frequency of intense precipitation events in some regions of the world, accompanied by changes in the frequency of dry days in some regions. The results of these analyzes indicated that the world has become warmer and wetter. Wet periods tend to produce significantly higher rainfall totals and events of heavy rain have become more frequent during the second half of the 20th century.

Haylock et al. (2006) studied changes in total precipitation and extreme precipitation over the period 1960 to 2000 and founded significant reductions in precipitation indicators in southern Peru and southern Chile. As a result, it showed a trend of decrease of consecutive dry days (CDD) and increased rates of consecutive wet days (CWD), maximum rainfall in one and five days (RX1DAY and RX5DAY) and heavy rains (R95P).

Zhou et al. (2014) projected the indexes of events extremes of temperature and precipitation in China using CMIP5 ensemble. They realize that compared to the reference period of 1986 to 2005, substantial changes are projected in temperature and precipitation extremes under different emission scenarios (rcp4.5 and rcp8.5). These changes include a decrease in cold extremes, an increase in warm extremes, and an intensification of precipitation extremes. In other hand other researches (SILLMANN et al., 2013) shows that changes in indexes based on daily minimum temperatures are found to be more pronounced than in indexes based on daily maximum temperatures, and in some regions (such as Australia, Central America, South Africa, and the Mediterranean), the indexes indicates future intensification of dry conditions.

Some models has been used as a tool to help studies to evaluate the impacts of climate changes in different sectors, as agriculture, health, industry, and others. However, this models has some errors due different factors making necessary some evaluation before the utilization. This errors occurs due to the parametrization necessary in this models and also due to the streamline 
equations in order to describe a chaotic system. This issue make essential to conduct research in order to verify the regions where these errors are more prominent. This errors can show for example if the model has tendency to underestimate or overestimate a particular variable for a given region.

The aim of this research is evaluate the climate scenarios given by CMIP5 models by studying the associated errors of this modeling. In this paper we intend to indicate between a select range of models the best ones to work for the region of Urbana-Champaign (United States), considering some specifics errors. This region is part of an important zone that have important place in the production of soybean and corn. This can helps another researchers to choose the more adequate model to use to simulate climate in this region giving more accurate results to the research. Also, we intend to describe the climatology and the possible changes of climate and extreme events in the region according to different scenarios of projections.

\section{MATERIAL AND METHODS}

\subsection{STUDY AREA AND CLIMATOLOGICAL DATA}

The study area is the region of Urbana-Champaign, Champaign County, Illinois (United States). This region have humid continental climate. This area is located in an important region for production of corn and soybean. The meteorological observed data in the region was given from a meteorological station located by the coordinates $40.0839^{\circ} \mathrm{N}$ and $88.2403^{\circ} \mathrm{W}$ (Figure 1) and altitude of the region is 219 meters. The data set includes meteorological variables provided by the Water and Atmospheric Resources Monitoring Program. The daily data set is available from 1901 to 2015 and includes the variables: rainfall and maximum, minimum and average temperature. The daily data was used to describe the occurrence of extreme events in the region.

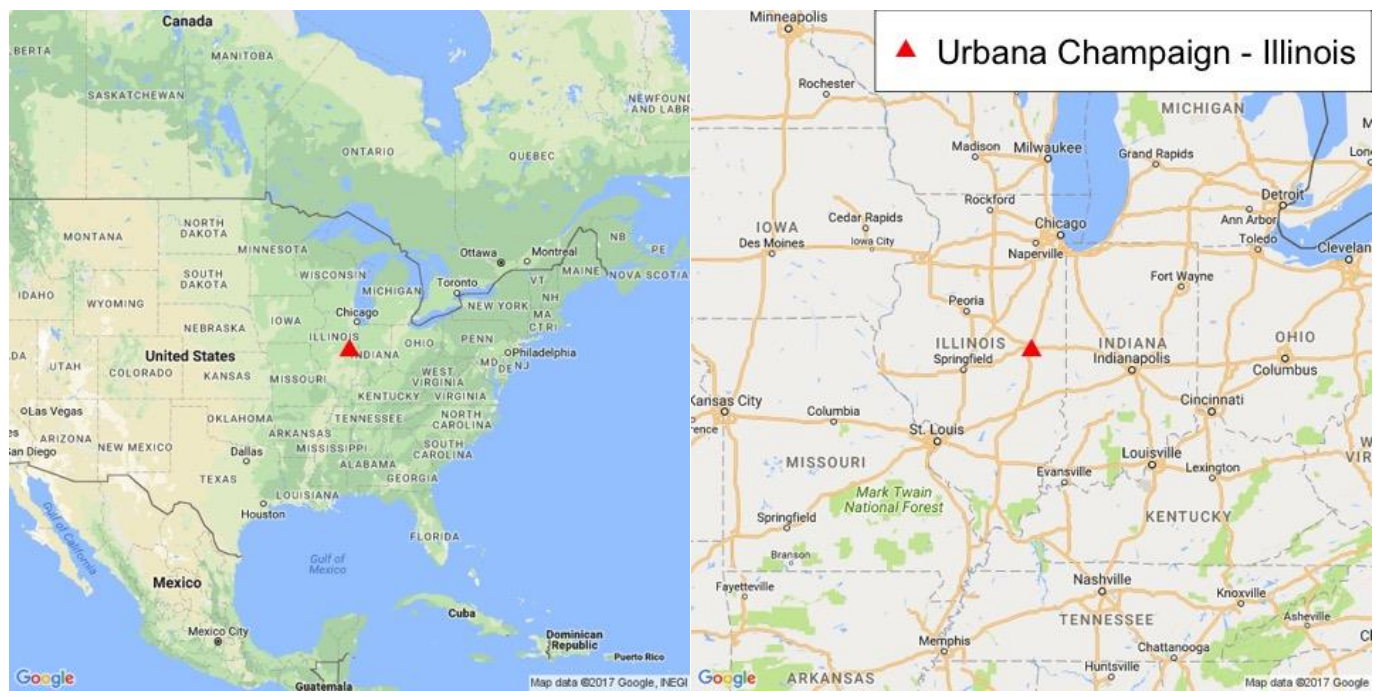

Figure 1 - Localization of Champaign (Illinois, USA). 
The monthly data from the weather station were analyzed in order to describe the climate in the area. It also sought to identify possible patterns of climate change from the analysis of the anomalies of the climatological variables. These anomalies were calculated from the deviation of the observation regarding the local climate. Thus, anomalies indicates the difference between each year and the average values of the period. In addition to the analysis of climatology and anomalies observed data also allowed the evaluation of climate projections models.

\subsection{CMIP5 CLIMATE PROJECTION MODELS AND ASSOCIATED ERRORS}

According the IPCC report (STOCKER et al., 2014) climate projection models simulate changes based on a set of scenarios.

A new set of scenarios, the Representative Concentration Pathways (RCP's) were created from long-term integrations with possible greenhouse gas emission scenarios in the atmosphere and their impacts on climate variables. These scenarios are used as input to weather and chemical modeling of the numerical experiments CMIP5 and was created for different ranges, as showed in Table 1. Research based on data developed by CMIP are widely used by the academic community.

Table 1 - Characterization of emission ranges of climate scenarios (RCP2.6, RCP4.5 and RCP8.5) from CMIP5 due to radiative forcing, as described by Moss et al. (2010).

\begin{tabular}{ll}
\hline Climate Scenario & Main forcing description \\
\hline RCP8.5 & $\begin{array}{l}\text { High emission scenario } \\
\text { Radiative forcing setting of } 8.5 \mathrm{~W} . \mathrm{m}^{-2} \text { ) }\end{array}$ \\
RCP4.5 & $\begin{array}{l}\text { Moderate emission scenario } \\
\text { (Radiative forcing setting of } 8.5 \mathrm{~W} . \mathrm{m}^{-2} \text { ) }\end{array}$ \\
RCP2.6 & $\begin{array}{l}\text { Low emission scenario } \\
\text { (Radiative forcing setting of } 8.5 \mathrm{~W} . \mathrm{m}^{-2} \text { ) }\end{array}$ \\
\hline
\end{tabular}

Figure 2 indicates that the surface temperature and precipitation changes according to different emission scenarios. In order to show more information about the different scenarios of emission in the CMIP5 models it is expose the Figure 3. In this figure it is projected the accumulation of $\mathrm{CO} 2$ and average temperature indicated by each scenario. 


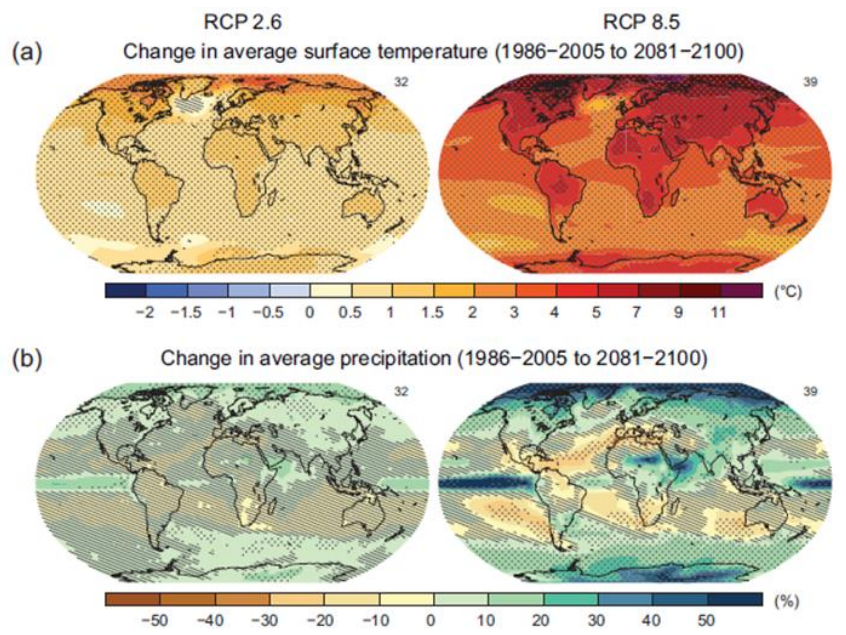

Figure 2 - Maps of the multi model CMIP5 for RCP2.6 and RCP8.5 simulated scenarios, considering the difference between the future years (2081 to 2100$)$ and the past years (1986 to 2005 can be also expressed as "current climate"), where: (a) the average of annual variation of surface temperature, (b) changes in the average percentage of annual precipitation. The number of CMIP5 models used to calculate the mean multi-model is shown in the upper right corner of each panel. Source: Stocker et al. (2014).

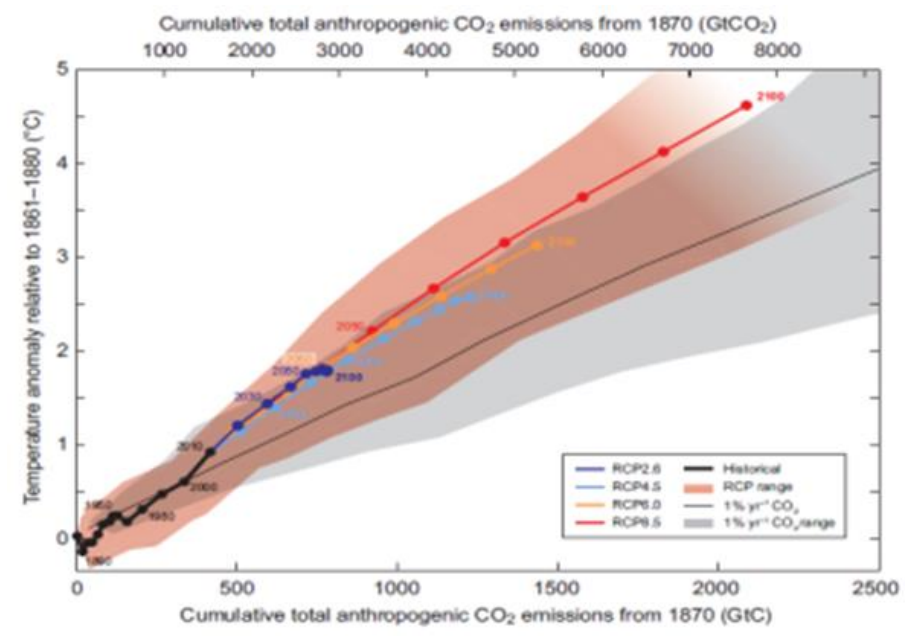

Figure 3 - Global increase of average surface temperature as a function of the total emission of CO2 accumulated until 2100. Source: Stocker et al. (2014).

Among the CMIP5 data, 14 available models were selected. The daily data is from 1901 to 2100. Simulations were integrated as historical experiments (1901 to 2012) and RCP2.6, RCP4.5 and RCP8.5 (2006 to 2100). Table 2 indicates the chosen models, their respective research centers, home countries and horizontal resolution. Using historical data is possible to compare the observed data from meteorological stations with the models projections and identify errors from the projections. The climatic variables precipitation and temperature (average, maximum and minimum) were analyzed. 
Table 2 - Models from CMIP5 with simulations of rcp4.5, rcp6 and rcp8.5 scenarios of climate changes.

\begin{tabular}{|c|c|c|c|}
\hline Model & Country & Center & Resolution \\
\hline BCC-CSM & China & Beijing Climate Center & $2.8^{\circ} \times 2.8^{\circ}$ \\
\hline CanESM2 & Canada & $\begin{array}{l}\text { Canadian Centre for Climate Modelling and } \\
\text { Analysis }\end{array}$ & $2.8^{\circ} \times 2.8^{\circ}$ \\
\hline CNRM-CM5 & France & $\begin{array}{l}\text { Centre Europeen de Recherche et Formation } \\
\text { Avancees em Calcul Scientifique }\end{array}$ & $1.4^{\circ} \times 1.4^{\circ}$ \\
\hline FGOALS-G2 & China & Institute of Atmospheric Physics & $3.1^{\circ} \times 2.8^{\circ}$ \\
\hline GFDL-CM3 & USA & Geophysical Fluid Dinamics Laboratory & $2^{\circ} \times 2.5^{\circ}$ \\
\hline GFDL-ESM2G & USA & Geophysical Fluid Dinamics Laboratory & $2^{\circ} \times 2.5^{\circ}$ \\
\hline GFDL-ESM2M & USA & Geophysical Fluid Dinamics Laboratory & $2^{\circ} \times 2.5^{\circ}$ \\
\hline IPSL-CM5A-LR & France & Institut Pierre-Simon Laplace & $1.9^{\circ} \times 3.8^{\circ}$ \\
\hline IPSL-CM5-MR & France & Institut Pierre-Simon Laplace & $1.3^{\circ} \times 2.5^{\circ}$ \\
\hline MIROC5 & Japan & $\begin{array}{l}\text { Atmosphere and Ocean Research Institute, } \\
\text { National Institute for Environmental Studies, } \\
\text { and Japan Agency for Marine-Earth Science } \\
\text { and Technology }\end{array}$ & $1.4^{\circ} \times 1.4^{\circ}$ \\
\hline MPI-ESM-LR & Germany & Max-Planck-Institut für Meteorologie & $1.9^{\circ} \times 1.9^{\circ}$ \\
\hline MPI-ESM-MR & Germany & Max-Planck-Institut für Meteorologie & $1.9^{\circ} \times 1.9^{\circ}$ \\
\hline MRI-CGCM3 & Japan & Meteorological Research Institute & $1.1^{\circ} \times 1.1^{\circ}$ \\
\hline NORESM1M & Norway & Norwegian Climate Centre & $1.9^{\circ} \times 2.5^{\circ}$ \\
\hline
\end{tabular}

Scientific papers often use some index to evaluate this errors (STONE, 1993; SAGHAFIAN; BONDARABADI, 2008; DALY et al., 2002; BASISTHA; ARYA; GOEL, 2008; WEI; LI; LIANG, 2005). The analyzed indexes were Mean Bias Error (MBE), Mean Absolute Error (MAE), Root Mean Square (RMSE), systematic part of the RMSE (RMSES), unsystematic part of the error RMSE (RMSEus), correlation (C), R square (R2). These indexes are calculated from the equations below.

$$
\begin{aligned}
& M B E=N^{-1} \sum_{i=0}^{n}\left(P_{i}-O_{i}\right) \\
& M A E=N^{-1} \sum_{i=0}^{n}\left|P_{i}-O_{i}\right| \\
& R M S E=N^{-1} \sum_{i=0}^{n} \quad \sqrt{\left(P_{i}-O_{i}\right)^{2}} \\
& R M S E_{S}=N^{-1} \sum_{i=0}^{n} \quad \sqrt{\left(P_{i}^{\prime}-O_{i}\right)^{2}} \\
& R M S E_{\text {us }}=N^{-1} \sum_{i=0}^{n} \quad \sqrt{\left(P_{i}^{\prime}-P_{i}\right)^{2}} \\
& C O R_{O P}=N^{-1} \sum_{i=0}^{n} \quad \cdot \frac{\left(o_{i}-\mu_{o}\right)\left(P_{i}-\mu_{p}\right)}{\sqrt{\left(P_{i}-P_{i}{ }^{\prime}\right)\left(P_{i}-\mu_{p}\right)}} \\
& R^{2}=1-\frac{S S_{\text {res }}}{S S_{\text {tot }}}
\end{aligned}
$$


$N$ is the number of observations, $\mathrm{Pi}$ means the predicted values and $\mathrm{Oi}$ are the observed data. $P i^{\prime}$ is the result of the linear regression between $P i$ and Oi. SSres and SStot are the sum of squares of residuals and total sum of squares, respectively.

The Mean Bias Error (MBE) is used in order to show information about the performance of the model in long term. The positive values indicates overestimation and negative values indicates underestimation. However, caution is necessary when using this index. Positive values can be canceled by negative values, showing erroneously low error values. For this reason a good approach is analyze MBE with the Mean Absolute Error (MAE). The MAE accumulate the errors, independently of the signal. According to Carvalheiro et al. (2008), MAE indicates the distance from the predicted values to the observed values.

Root Mean Square (RMSE) provides information about the performance of the model in short term. In this case, the lower the value, the lower the dispersion of data around the model. The handicap is that a few outliers can generate a significant increase in its magnitude. The RMSE can be divided in systematic and unsystematic errors. The systematic errors show the tendency of the model in sub or overestimate a variable. The unsystematic error is the intrinsic error of the model.

Correlation indicates the meaning statistical relationships between two or more random variables or observed data values. $R$ square $\left(R^{2}\right)$ is a number that indicates the proportion of the variance in the dependent variable that is predictable from the independent variable, and vary from 0 to 1 . A bigger value of R2 means that the model has good adjustment to the observation.

The climate model errors are calculated from the historical experiment (1900 to 2012) and from data collected in meteorological stations in the region for the same period. The variables analyzed were rainfall, maximum, minimum and average temperature. After the statistical analysis of the performance of the models in the simulation of climatic conditions of the area it was possible to infer about the model with minor errors in the projections.

\subsection{EXTREME EVENTS DETECTION}

The studied climate extremes indexes were proposed by the World Meteorological Organization (WMO) and the Climate Research Program Variability and Predictability (CLIVAR) in order to enable the comprehensive analysis of extremes. Studies about the occurrence of these events are important because the increase frequency or severity of extreme weather events are directly associated with human and monetary losses. Extreme climate events and their changes are very important due to their strong impacts in society. The Special Report on Extreme Events (SREX) of the Intergovernmental Panel on Climate Change (STOCKER et al., 2014) emphasized this impact.

Due to this issue the selected indexes Table 2 was calculated in order to quantify the occurrence of these extremes on observed and projected data and evaluate how accurate the models can simulate extreme events. To analyze this data we use the boxplot chart. This chart gives the variability of the indexes between the studied years facilitating the comparison between the projections of 
the models in historical simulation (1901 to 2012). Besides, the chart can also shows the median values and the limier that represents $50 \%$ of the data.

Table 2 - Indexes for measure the extreme events.

\begin{tabular}{|c|c|c|}
\hline Index & Description & Unit \\
\hline RX1DAY & Maximum rainfall (RR) occurred in one day over the period. & $\mathrm{mm}$ \\
\hline RX5DAY & Maximum RR occurred in interval of five days over the period. & $\mathrm{mm}$ \\
\hline CDD & $\begin{array}{l}\text { Consecutive Dry Days. Maximum number of consecutive days with RR } \\
<1 \mathrm{~mm} \text {. }\end{array}$ & days \\
\hline CWD & $\begin{array}{l}\text { Consecutive wet days. Maximum number of consecutive days with } \\
\mathrm{RR} R R \geqslant 1 \mathrm{~mm} \text {. }\end{array}$ & days \\
\hline SU & Number of summer days: Annual count of days when $\mathrm{TX}>25^{\circ} \mathrm{C}$. & days \\
\hline FD & Number of frost days: Annual count of days when $\mathrm{TN}<0^{\circ} \mathrm{C}$. & days \\
\hline ID & Number of icing days: Annual count of days when $\mathrm{TX}<0^{\circ} \mathrm{C}$ & days \\
\hline TXX & Maximum value of daily maximum temperature. & ${ }^{\circ} \mathrm{C}$ \\
\hline TXn & Minimum value of daily maximum temperature & ${ }^{\circ} \mathrm{C}$ \\
\hline TNx & Maximum value of daily minimum temperature & ${ }^{\circ} \mathrm{C}$ \\
\hline TNn & Minimum value of daily minimum temperature & ${ }^{\circ} \mathrm{C}$ \\
\hline DTR & Daily temperature range: Mean difference between TX and TN & ${ }^{\circ} \mathrm{C}$ \\
\hline
\end{tabular}

\section{RESULTS AND DISCUSSION}

\subsection{CLIMATOLOGICAL ANALYSIS}

The climatological analysis of the region it was made in order to identify patterns in the historical data. In Figure 4 the heat maps indicates the seasonality of observed data of precipitation $(\mathrm{mm} / \mathrm{month})$ and average temperature $\left({ }^{\circ} \mathrm{C}\right)$. This data it was given from a meteorological station in Urbana, Illinois. In total is displayed 115 years of monthly data. It is found that the region does not have a well-defined rainy season, because despite the summer (June to September) is the season with the highest rainfall, these also occur with some frequency in other seasons. The month of July of 1992 was showed as the wettest month of the climatology, with monthly rainfall around $352 \mathrm{~mm}$. Studying the climatology of this area it was noted that by the year of 1970 , only twice the area had experienced monthly accumulation greater than $25 \mathrm{~cm}$ (1902 and 1943). However, from 1971 to the year 2013, there were 5 times monthly accumulations of greater precipitation than $25 \mathrm{~cm}(1971,1977$, $1985,1992,1993,1995)$. Regarding the temperature, it is observed that the seasons are well defined, with an average temperature of $23^{\circ} \mathrm{C}$ in summer (June to September) and $-2^{\circ} \mathrm{C}$ in winter (December to March). 

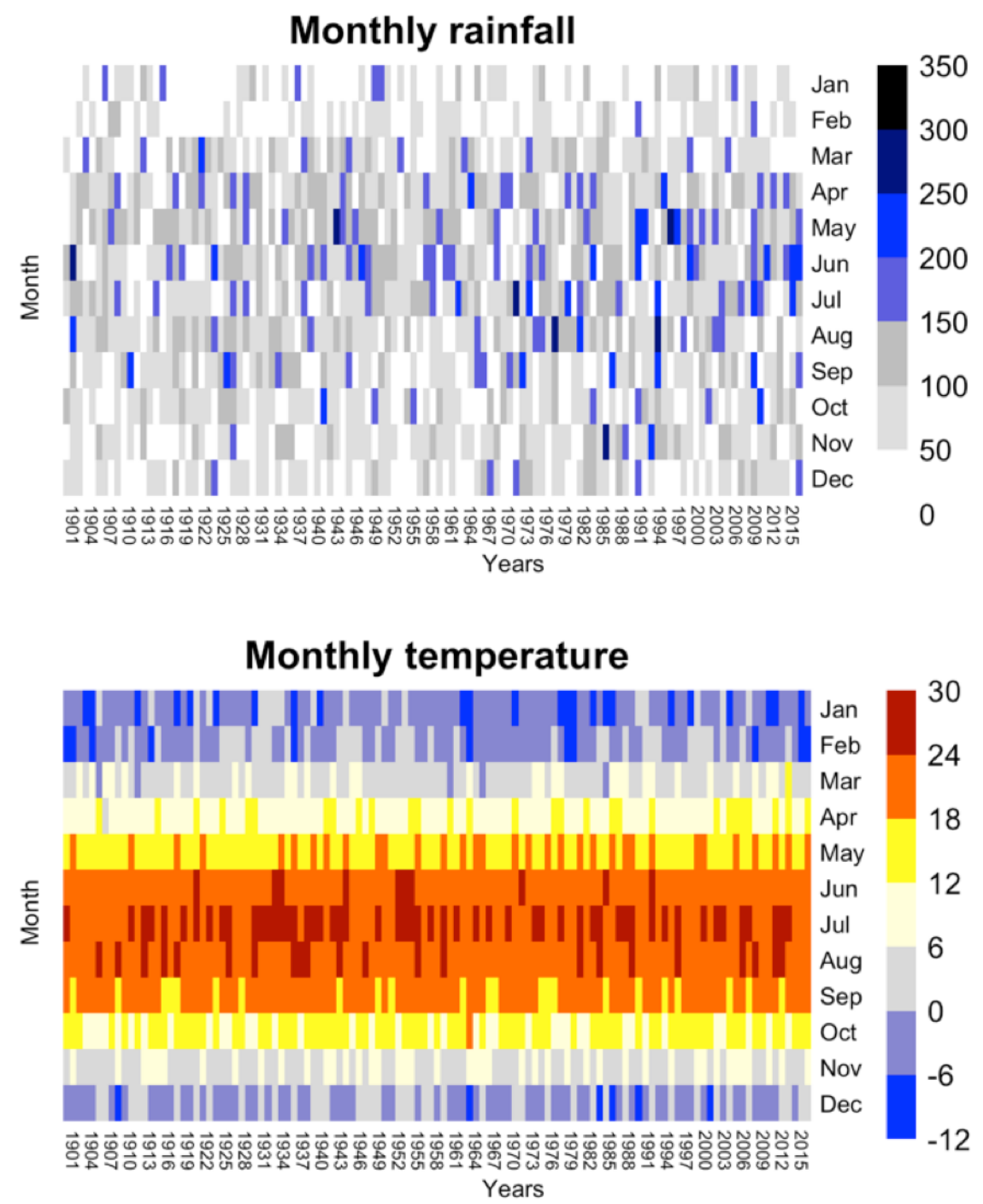

Figure 4 - Variation if monthly accumulated precipitation and average temperature in the region of Urbana-Champaign (Illinois, USA) between 1901 to 2013.

Figure 5 shows the behavior of precipitation and temperature (average, maximum and minimum) between the years of 1901 and 2015. Analyzing the values of annual accumulated precipitation is found that the rainfall is very variable to over the years. The average annual rainfall is $968.8 \mathrm{~mm}$ and is represented on the chart (left) by a straight line. The dotted line shows the tendency of increase of precipitation over the years. The chart also shows the average temperatures, maximum and minimum observed. The average of these variables are: $11.1^{\circ} \mathrm{C}, 16.5^{\circ} \mathrm{C}, 5.7^{\circ} \mathrm{C}$, respectively. It is noted that the temperature variables are highly correlated. There is a small tendency of increase of this temperatures over the years. This tendency is represented by the dotted line. 
From the annual average, it is difficult to identify patterns in the variables that may be taken as evidence of changes in climate region. One way to try to identify patterns to evaluate anomalies of the variables in relation to the climatology (Figure 6).
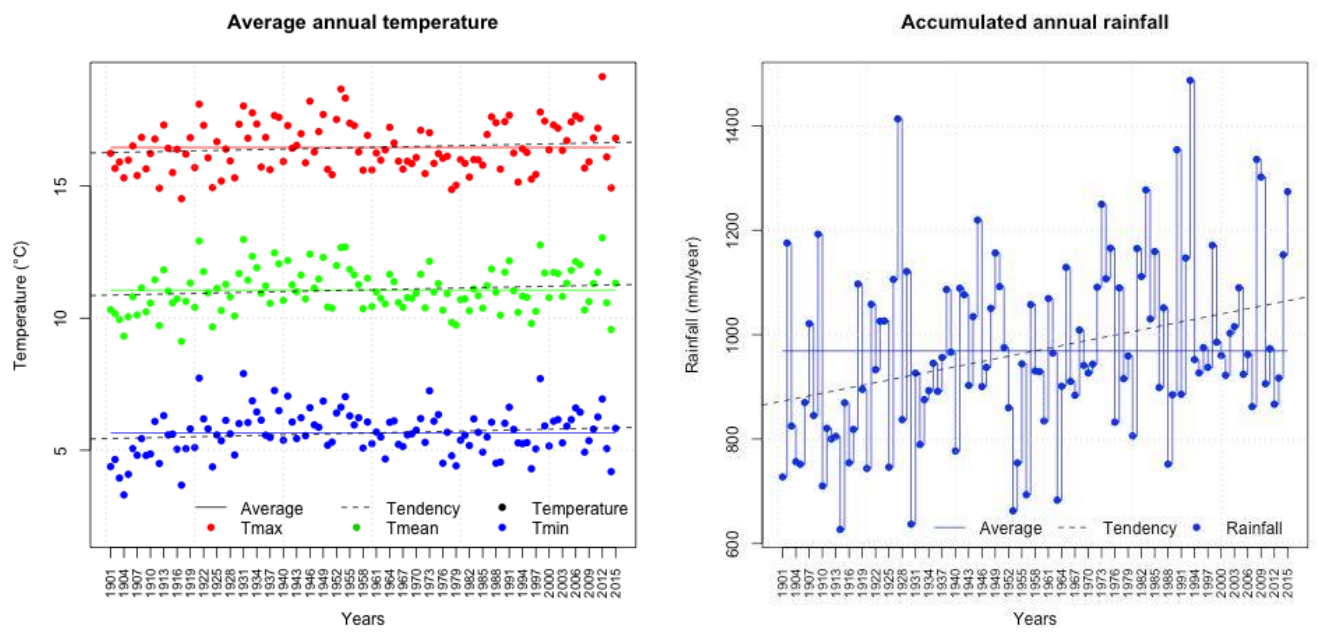

Figure 5 - Variation of precipitation and temperature in the region of Urbana-Champaign (Illinois, USA), from 1901 to 2013.
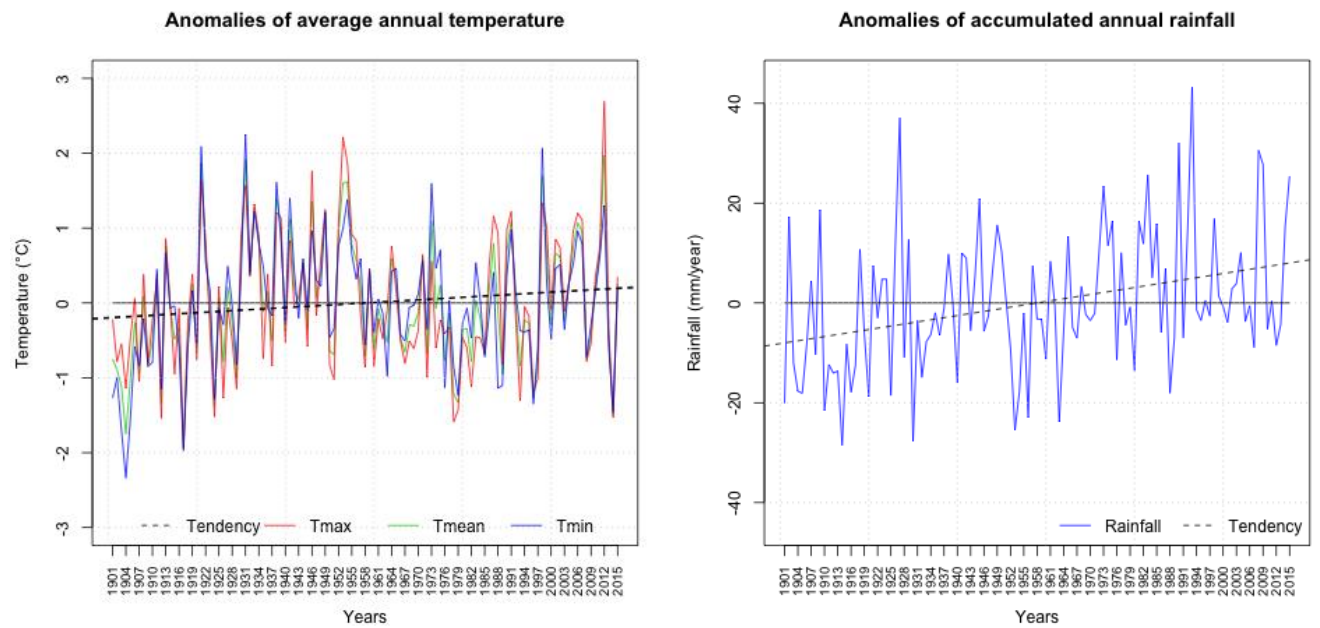

Figure 6 - Anomalies of observed precipitation accumulated per year and average temperature per year (maximum, minimum and average) in Urbana-Champaign (IL, USA) between the period 1901 to 2015.

The study of precipitation anomalies indicates a small upward trend in the positive anomaly of precipitation in recent years, mainly from the year 1965 . Regarding to the temperature, notably at the beginning of the 20th century tended to be negative, then began to increase until the middle of 1950 . Between the late 1950s and early 1980s, it is possible identify a reduction in the anomalies (highly positive for highly negative) and a reduction in the mean temperature during this period. Some hypotheses may explain this change in 
temperature patterns. These might be related to the presence of aerosols in the atmosphere.

Some aerosol particles (such as sulfate) alter the Earth's energy balance reflecting and scattering solar radiation back into space. This reduce the amount of radiation reaching the Earth's surface and thus cools the surface. The most likely hypothesis is based on a working (TEGEN, 1990) which infers that since 1950 there was significant growth of aerosol emissions in the US, mainly sulfate. Since 1980 however, there was a reduction of the emission of this component, based on campaigns as "Clean Air Act." There are other hypothesis such as that shown in Handler (1985) which relates volcanic activities throughout the world, with the amount of aerosol in the atmosphere. Another explanation for variations in temperature anomaly can be based on fluctuations in the ocean heat transport, which can contribute to multidecadal climate variations.

These results agree with the results found by Hansen et al. (2001) which identifies global warming patterns between the years 1900 and 1940 and cooling between the years 1940 and 1965.

\subsection{EXTREME EVENTS OCCURRENCE}

Regarding to the occurrence of extreme precipitation and temperature events the Figures 8 and 9 shows the indexes calculated for the area, considering observed data.
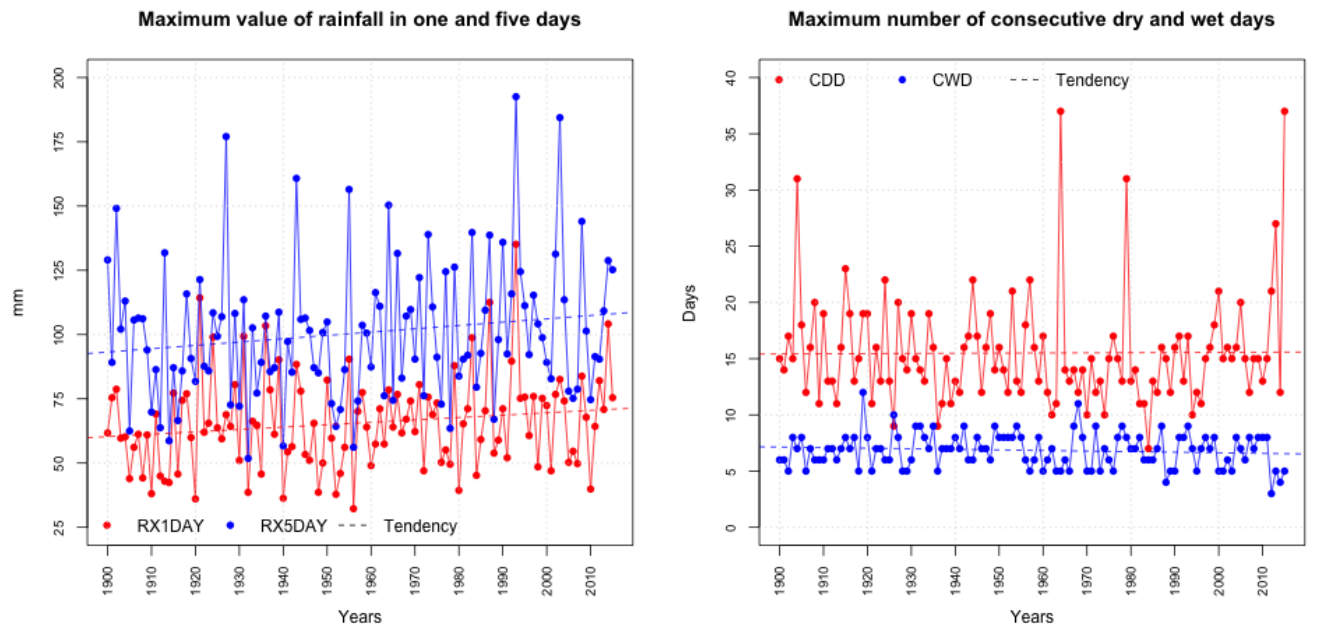

Figure 8 - Extreme events of precipitation, considering observed data from 1901 to 2015. The dashed line means the tendency of each index, the letter presents the index of maximum value of rainfall in one and five days (RX1DAY, RX5DAY) and the maximum number of consecutive dry and wet days (CDD, CWD).

Considering the accumulated precipitation in one day (RX1DAY) and five consecutive days (RX5DAY), this indexes has tendency of increasing over the years. The biggest event of RX1DAY occur in the year 1993 and had a value of 135.13 millimeters. Regarding to RX5DAY, in the same year the index reached the highest value of 192.53 millimeters of accumulated precipitation in five 
consecutive days. Ten years later (2003) the index reached the value of 176.23 millimeters. This value occur just once in the first 90 years of analysis, in 1927 with 177.03 millimeters. So it is noticed that the highest values occur in the last 30 years.

In relation to the consecutive dry and wet days (CDD and CWD), it is noticed that the index CWD does not have a large variance. But considering the CDD index, until 1960 the occurrence of more than 30 dry days happened just once (1904, 31 days). However, after 1960 this occurrence can be seen four times in 1964 (37 days), 1979 (31 days), 2002 (33 days), 2015 (37 days). With this data we can presume that the case of years with long period without rainfall is increasing, which could be a problem for different sectors as agriculture and energy. The extreme events of temperature are represented by the indexes: minimum value of minimum and maximum temperature (TNn and TXn), maximum value of minimum and maximum temperature (TNx and TXx), daily temperature range (DTR), number of summer days (SU), number of frost days (FD), number of icing days (ID).
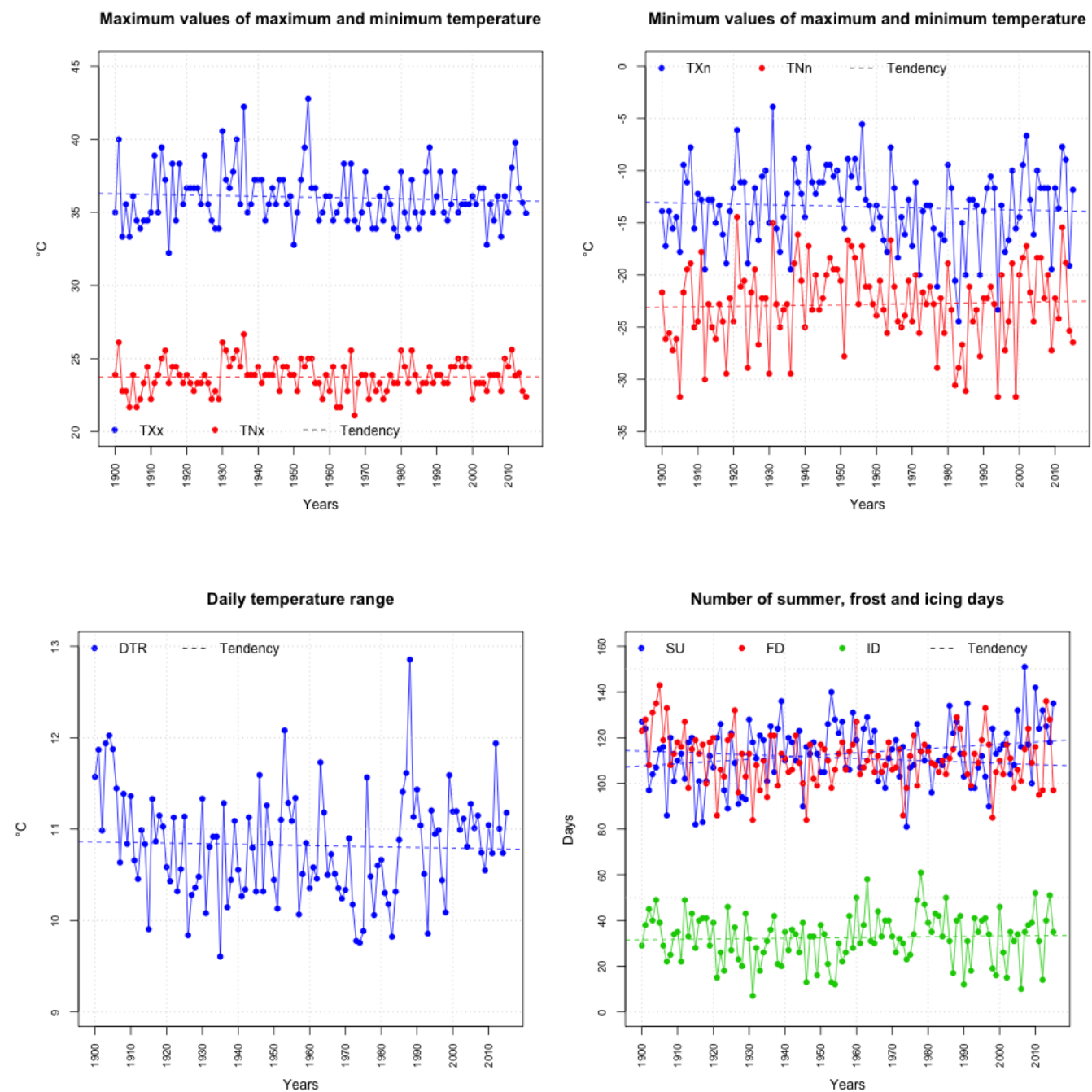

Figure 9 - Extreme events of temperature, considering observed data from 1901 to 2015. The dashed line means the tendency of each index: maximum value of maximum 
and minimum temperature ( $T X x, T n x)$, minimum value of maximum and minimum temperature (TXn, TNn), daily temperature range (DTR) and number of summer, frost and icing days (SU, FD and ID).

Through the Figure 9 it is noticed that in this region does not exist a tendency of decreasing or increasing of TNx and TNn. For the TXx index is perceived that the maximum of the maximum temperature reached more than $40^{\circ} \mathrm{C} 4$ times until the year of 1954 . After this year, there is no occurrence of any day with maximum daily temperature higher than $40^{\circ} \mathrm{C}$. In other hand, when it is analyzed the number of summer days, the occurrence of this index with values higher than 130 days happened about 9 times (years) in the whole period studied (1901-2015). But it is also noticed that in 7 of this 9 times it happened in the last 30 years $(2015,2012,2010,2007,2005,1991,1986)$. This tendency of increasing of SU could be an indicative of global warming, considering that the summer days is those days with daily temperature higher than $25^{\circ} \mathrm{C}$.

Considering the number of frozen days (annual count of days when TX > $25^{\circ} \mathrm{C}$ ) we identify a tendency of decrease of this events. Apart from this fact, it is also noticed that more than 130 days of this events in a year occur 5 times between 1900 and 1926. However, after this year (from 1927 to 2015) this magnitude of event occur just once (in 2013). This fact may indicate that the region is not that cold how it is used to be. For the number of icing days, in 6 events this index was above 50 days in a year. All of this events happened after 1960 (1960, 1963, 1978, 1985, 2010, 2014). The amplitude of daily temperature is decreasing although in 1988 was the highest value.

\subsection{STATISTICAL ANALYSIS OF ERRORS}

The statistical analysis of the climate in the region can help us to identify the model which has better accuracy in the study region. The Figure 10 indicates the statistic errors for the maximum, minimum and average temperature and also for the precipitation.

From the Figure 10 it is revealed that generally the models has tendency to underestimate the precipitation considering the Mean Bias Error (MBE). This is observed by the negative values of MBE. Those models also tends to underestimate the maximum and average temperature (Tmax, Tmean) and overestimate the minimum temperature (Tmin) in the historical simulation. Examining the Mean Absolute Error (MAE) it is found that the maximum temperature and precipitation has the lowest values of error. The model with lower MAE was IPSL-CM5-MR and the model with highest value was CANESM2. IPSL-CM5-MR shows underestimation of Tmax, Tmean and precipitation. Regarded to CANESM2 model it is observed a large trend of overestimation of temperatures (maximum, minimum and average) and overestimation of precipitation. 


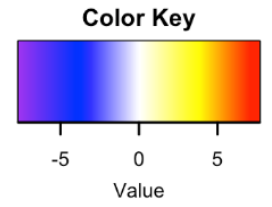

\section{Mean (Absolute and Bias) Error}

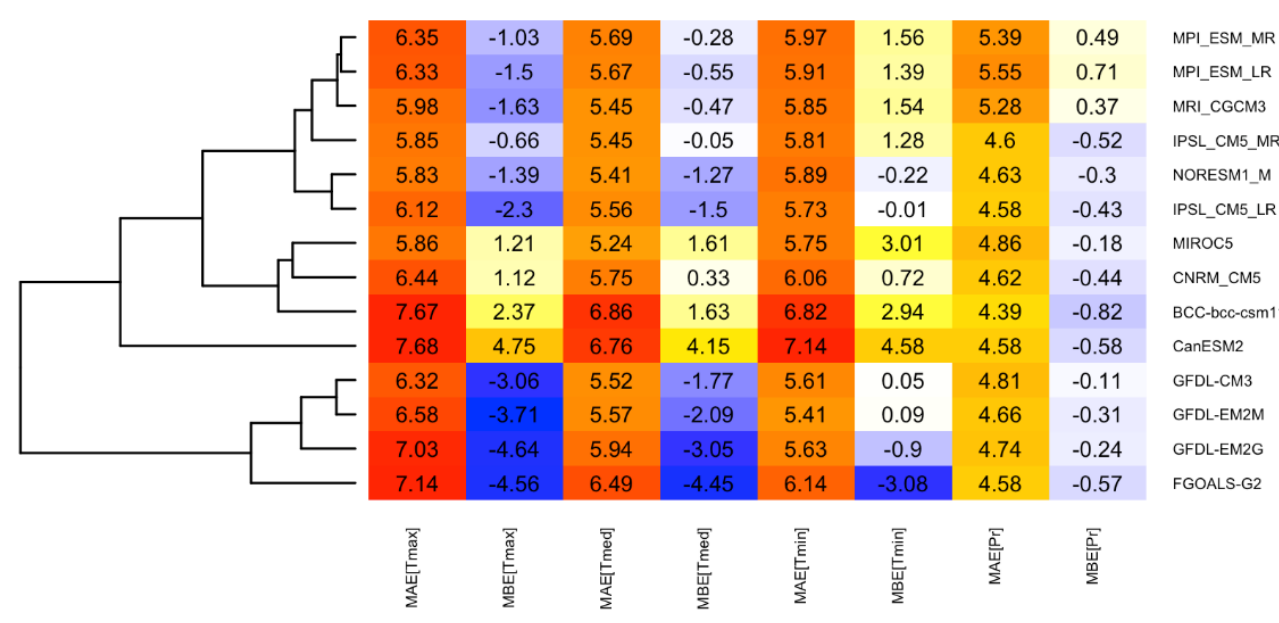

Figure 10 - Statistical analysis of errors of temperature (maximum, average and minimum) and precipitation in the climate models, based on mean (absolute and bias) error (MAE, MBE), root mean square error (RMSE) considering systematic and unsystematic errors, and correlation and coefficient of determination R2. (Continue)

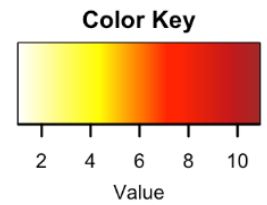

\section{Root Mean Square Error}

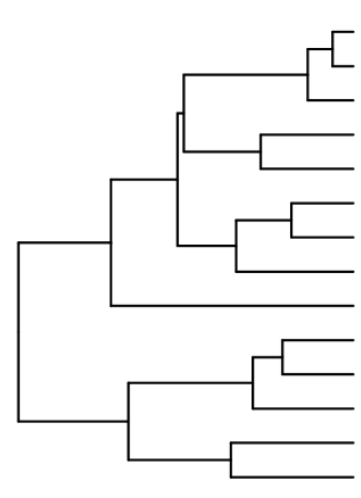

\begin{tabular}{|c|c|c|c|c|c|c|c|c|c|c|c|}
\hline 8.05 & 3.81 & 7.09 & 7.31 & 2.61 & 6.83 & 7.67 & 2.75 & 7.16 & 10.73 & 7.93 & 7.22 \\
\hline .98 & 3.78 & 7.03 & 7.25 & 2.54 & 6.79 & 7.58 & 2.59 & 7.12 & 10.9 & 7.9 & 7.5 \\
\hline 67 & 3.56 & 6.79 & 7.09 & 2.53 & 6.63 & 7.6 & 2.93 & 7.01 & 10.55 & 7.92 & 6.96 \\
\hline 86 & 2.98 & 7.28 & 7.24 & 2.01 & 6.96 & 7.45 & 1.5 & 7.3 & 9.5 & 7.86 & 5.33 \\
\hline 7.4 & 3.77 & 6.38 & 7.01 & 2.69 & 6.48 & 7.6 & 2.24 & 7.27 & 9.23 & 7.86 & 4.8 \\
\hline 8.09 & .03 & .84 & 7.29 & 1.56 & .12 & 7.67 & 2.13 & 7.36 & 9.89 & 7.92 & 5.9 \\
\hline 47 & 1.6 & 7.3 & 6.97 & 1.05 & 6.89 & 7.41 & 1.85 & 7.18 & 1.86 & 7.96 & 5.8 \\
\hline 7.4 & .65 & 7.22 & 6.65 & 1.96 & 6.35 & 7.26 & 3.46 & 6.39 & 10.14 & 7.92 & 6.33 \\
\hline 44 & 2.55 & 9.09 & 8.54 & 1.63 & 8.38 & 8.58 & 3.01 & 8.03 & .61 & 7.98 & 5.34 \\
\hline 85 & 5.29 & 7.1 & 7.56 & 3.67 & 6.61 & 7.19 & 2.47 & 6.75 & 9.57 & 7.92 & 5.36 \\
\hline 29 & 4.49 & 6.97 & 7.05 & 3.06 & 6.36 & 6.9 & 2.62 & 6.39 & 9.47 & 7.88 & 5.23 \\
\hline 94 & 4.76 & 6.36 & 7.03 & 3.71 & 5.97 & 7.22 & 3.59 & 6.26 & 9.66 & 7.93 & 5.51 \\
\hline 37 & 4.95 & 7.95 & 8.38 & 4.51 & 7.06 & 8.93 & 5.25 & 7.22 & 10.03 & 7.97 & 6.09 \\
\hline 05 & 4.59 & 7.8 & 8.33 & 4.53 & 6.99 & 8.09 & 3.36 & 7.36 & 9.56 & 7.92 & 5. \\
\hline 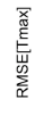 & 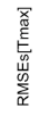 & 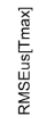 & 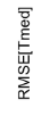 & 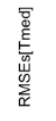 & 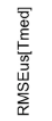 & 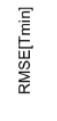 & 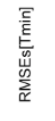 & 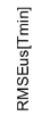 & $\stackrel{\overline{\underline{W}}}{\underline{\underline{W}}}$ & $\begin{array}{l}\bar{\Xi} \\
\frac{\bar{\omega}}{5} \\
\stackrel{w}{N} \\
\sum_{\alpha}^{n}\end{array}$ & 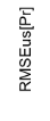 \\
\hline
\end{tabular}

MPI_ESM_MR MPI_ESM_LR MRI_CGCM3 IPSL_CM5_LR NORESM1_M CNRM_CM5 IPSL_CM5_MR MIROC5 BCC-bcc-csm11 GFDL-EM2G GFDL-EM2M GFDL-CM3 CanESM2 FGOALS-G2 


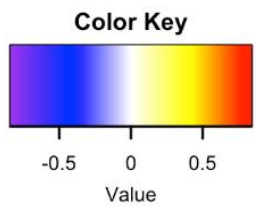

\section{Correlation and $\mathbf{R}$}

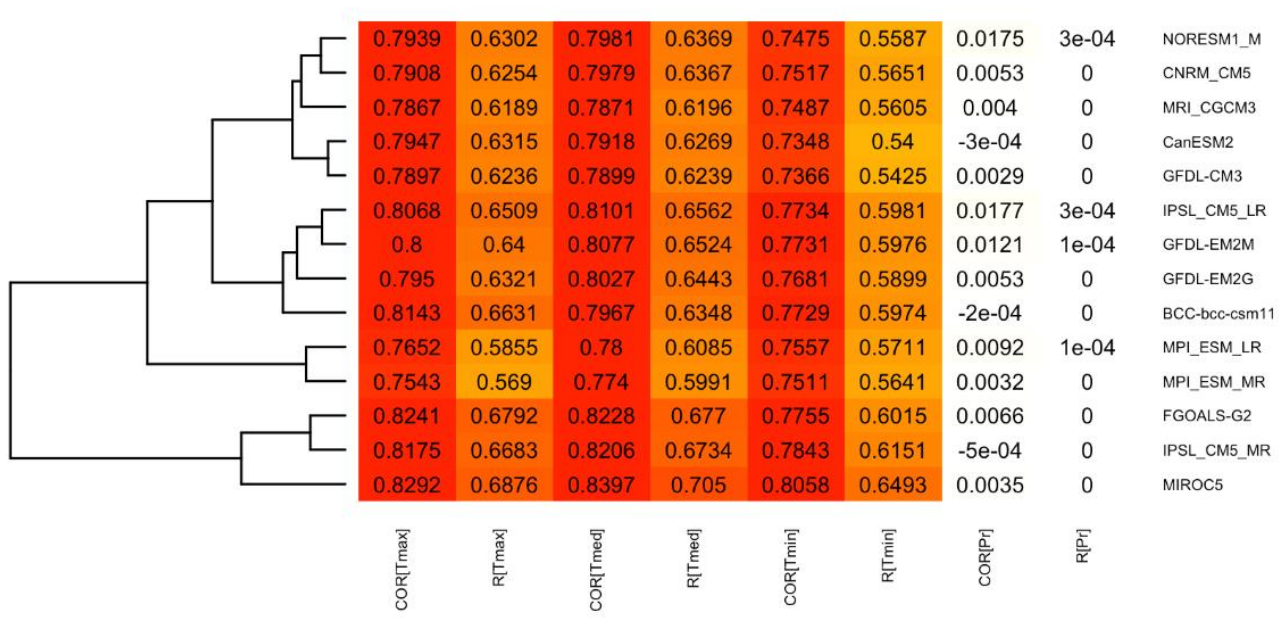

Figure 10 - Statistical analysis of errors of temperature (maximum, average and minimum) and precipitation in the climate models, based on mean (absolute and bias) error (MAE, MBE), root mean square error (RMSE) considering systematic and unsystematic errors, and correlation and coefficient of determination R2. (End)

Regarding to RMSE this error can be divided into systematic (RMSEs) and unsystematic (RMSEUs). The unsystematic part is, in most cases, higher than the systematic part. This make difficult the removal of the errors. Considering the precipitation, the RMSEs is barely bigger than RMSEs. However, RMSEs it was not removed due to the difficulty of doing this removal in a punctual variable. Considering the total RMSE, the highest values were found for the precipitation and the lowest values for average temperature. The model with lowest and highest values of RMSE were NORESM1-M and CANESM2, respectively. Correlation (C) and coefficient of determination (R2) are extremely low for precipitation. This is explained by the fact that this is a punctual variable. In other words, this is a variable which the prediction is very difficult. For example, the delay of one day in the predicted precipitation could lead to a very low correlation, even if the prediction was accurate regarding to the value of this variable. In a long term is very difficult to predict the exact day of a big rainfall, but it is important that the tendency of big amount of rainfall is correct.

The temperatures normally is easier to predict and for this reason this variable has higher $\mathrm{C}$ and $\mathrm{R} 2$. Figure 10 shows that the correlation of the observed temperature and simulations are higher than 0.7. The average temperature is the meteorological variable with higher correlation, compared to the others analyzed. The model with higher C and R2 is MIROC5. However, analyze the extreme events is even more important than the proper variable. This happened due to the effects of this extremes are more devastating.

Figures 11 and 12 shows the boxplot for the extreme events of precipitation and temperature. Considering the occurrence of extreme events of precipitation we can note that for the RX1DAY index there is a tendency of 
underestimation of most of models simulations. The model which the underestimation was lower compared to the other models was IPSL(CM5MR). For RX5DAY the models FGOALS(G2) and NORESM(1M) registered the lowest values of the index.
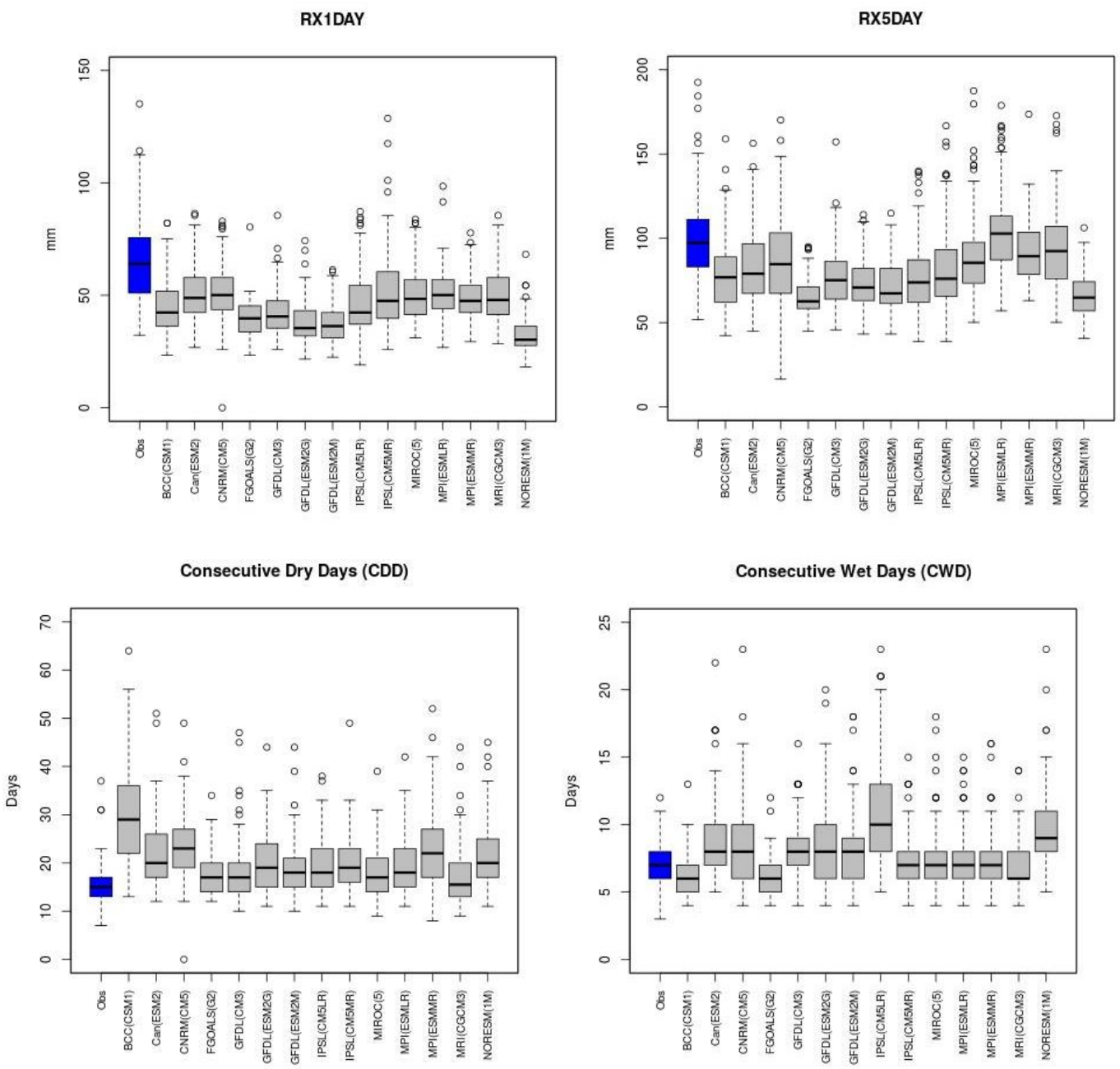

Figure 11 - Occurrence of extreme events of precipitation according to observed data (blue box) and climate models (grey box), between 1901 and 2015. The index are Maximum value of rainfall in one day (RX1DAY), Maximum value of rainfall in five days (RX5DAY), consecutive dry days (CDD), consecutive wet days (CWD).

Again, the model IPSL(CM5MR) and also the models MIROC5, MPI(ESMLR), MPI(ESMMR) and MRI(CGCM3) represented the best values (closest to the observed data). Regarding to the indexes CDD and CWD (consecutive dry and wet days) is noticed the tendency of overestimation of the indexes in simulations, mostly when the outliers are considered. For CDD the model with higher overestimation was BCC(CSM1) and for CWD the model IPSL(CM5LR). Again, the models with good representation of the index were: IPSL(CM5MR), MIROC5, MPI(ESMLR), MPI(ESMMR) and MRI(CGCM3). 

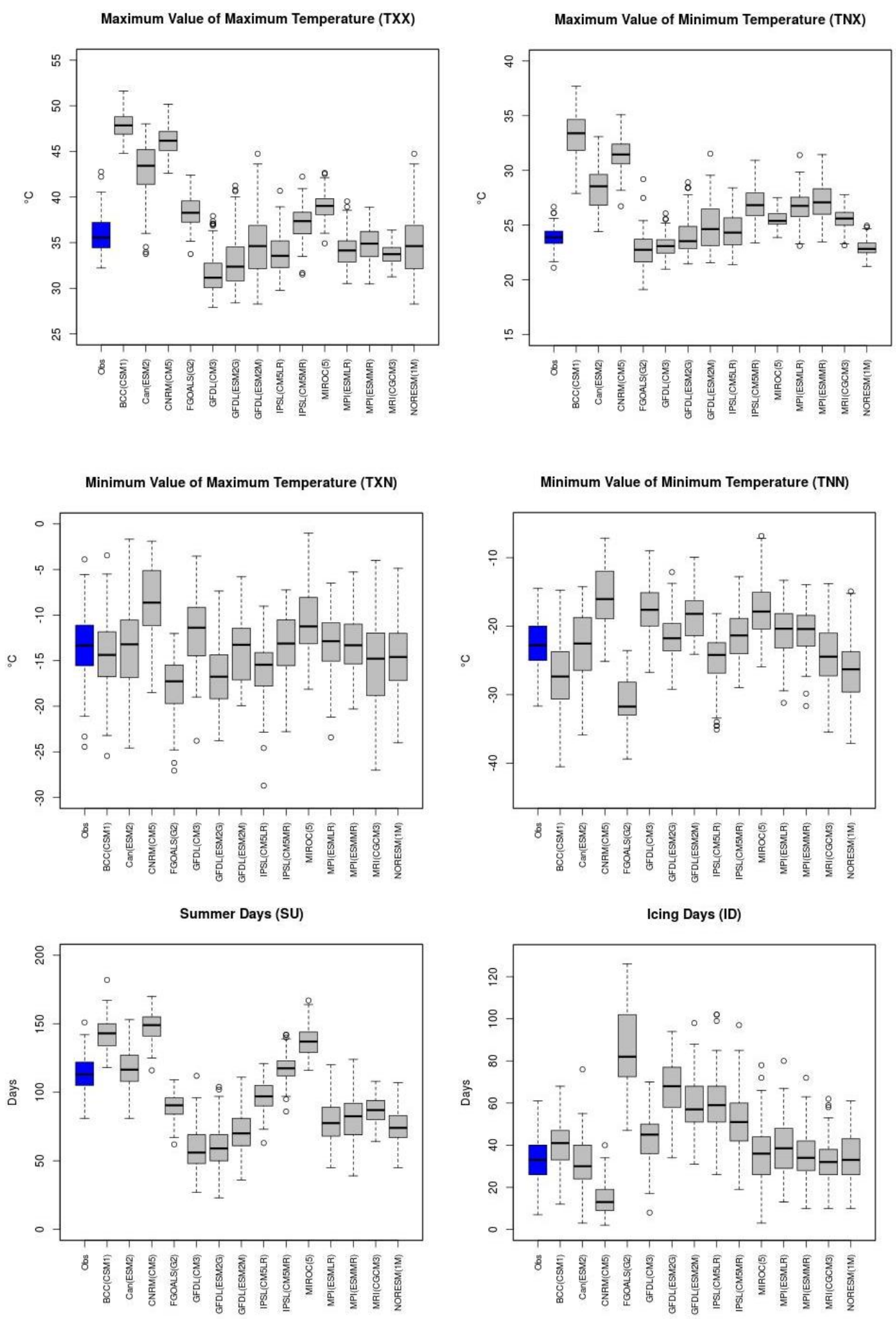

Figure 12 - Occurrence of extreme events of temperature according to observed data (blue box) and climate models (grey box), between 1901 and 2015. The index are maximum value of maximum (TXX) and minimum temperature (TNX), minimum value of maximum (TXn) and minimum temperature (TNn), summer days (SU), icing days (ID), frozing days (FD) and daily temperature range (DTR). (Continua) 

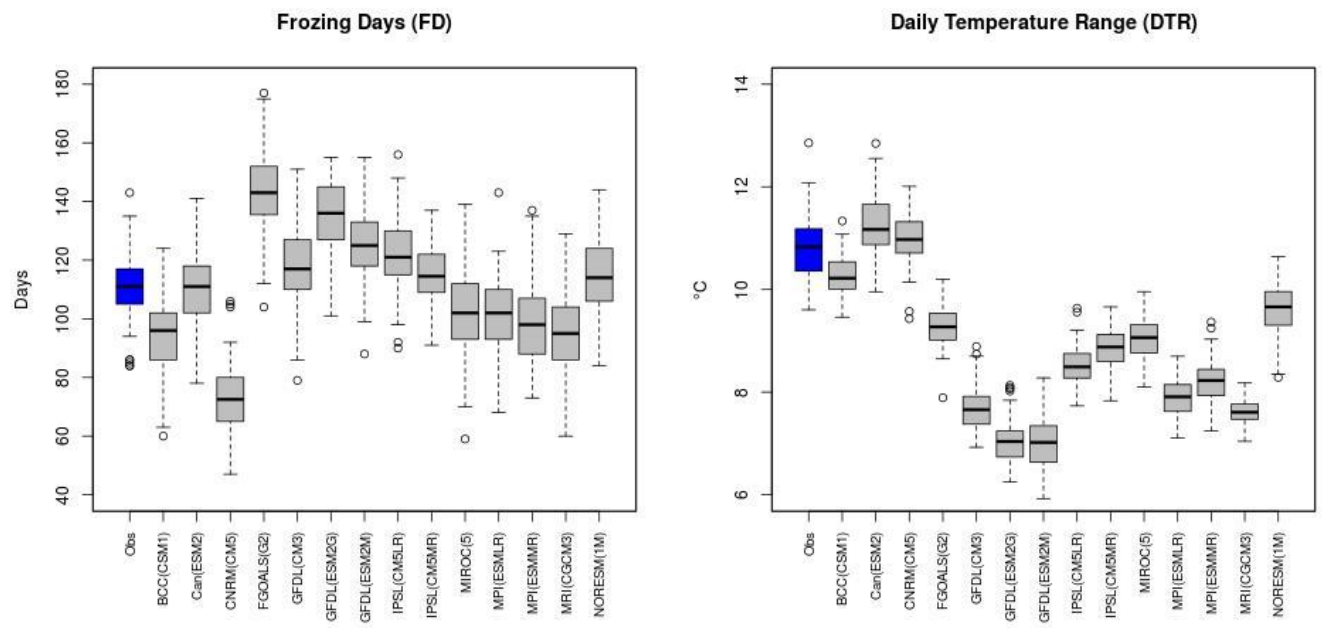

Figure 12 - Occurrence of extreme events of temperature according to observed data (blue box) and climate models (grey box), between 1901 and 2015. The index are maximum value of maximum (TXX) and minimum temperature (TNx), minimum value of maximum (TXn) and minimum temperature (TNn), summer days (SU), icing days (ID), frozing days (FD) and daily temperature range (DTR).

Figure 12 with TXx and TNx indexes indicates tendency of overestimation of those temperatures in some models. However, the tendency depends of the analyzed model. The models with higher overestimation were BCC(CSM1), Can(ESM2) and CNRM(CM5).

In relation to the index ID, is noticed that the model FGOALS(G2) shows high overestimation. DTR shows that some models has tendency of underestimation of the index. Regarding to SU, the models IPSL(CM5MR) and Can(ESM2) indicates good performance.

\subsection{CLIMATE PROJECTIONS SCENARIOS}

As observed in the previous section, the choice of a model to use in a specific location is not easy. There is a lot of factors that can have influence in this choice and depends mostly of the application of this data. In this case, for the region of Urbana-Champaign in Illinois state (USA) one model that showed good capacity to represent the meteorological variables and extreme events in the region of study was IPSL(CM5MR).

IPSL(CM5MR) was developed in France by the Institut Pierre-Simon Laplace. The horizontal grade is $1.3^{\circ} \times 2.5^{\circ}$. More information about this model can be found at https://verc.enes.org/models/earthsystem-models/ipsl/ipslesm. This model presented tendency of underestimation of precipitation and average and maximum temperature. Regarding to minimum temperature this models has tendency to overestimation. Regarding to the indexes of extreme events, we noticed that most of them showed good performance. However, is important highlight that the indexes ID shows overestimation and DTR shows underestimation. 
Climate projections scenarios of this model is given by Figure 13. Figure 13 shows the observed data (from 1901 to 2015) and simulated data. The simulated data are divided into historical (1901 to 2005) and RCP2.6, RCP4.5 and RCP8.5 (2006 to 2100). Regarding to the precipitation, the climate scenarios does not show any pattern. But it is also presented that the accumulated values can be higher in specific years. All scenarios of temperature projections indicates that this variable may increase in future. The scenario with higher increase was RCP8.5, which was expected considering that this scenario is the most pessimist in the analyzed projections. The same pattern is observed in maximum and minimum temperature, however, with different magnitudes. There is a discontinuity in the data within the historical simulation and the RCP's, which occur due to differences in the initial conditions of the RCP's. Figure 14 shows that indexes for precipitation.
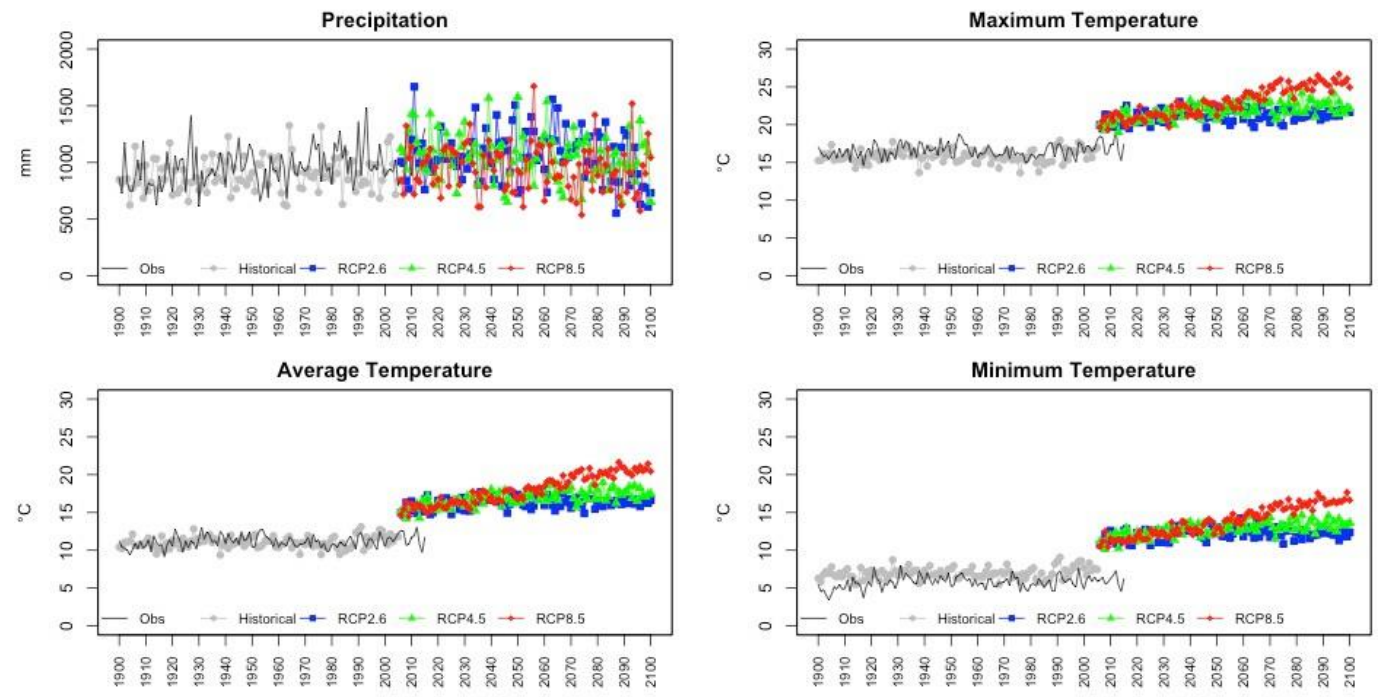

Figure 13 - Observed and simulated data of precipitation and maximum, average, and minimum temperature (projected by IPSL(CM5MR)) for 1901 to 2100 . The simulated data includes historical simulation (grey) and RCP2.6 (blue), RCP4.5 (green) and RCP8.5 (red). 

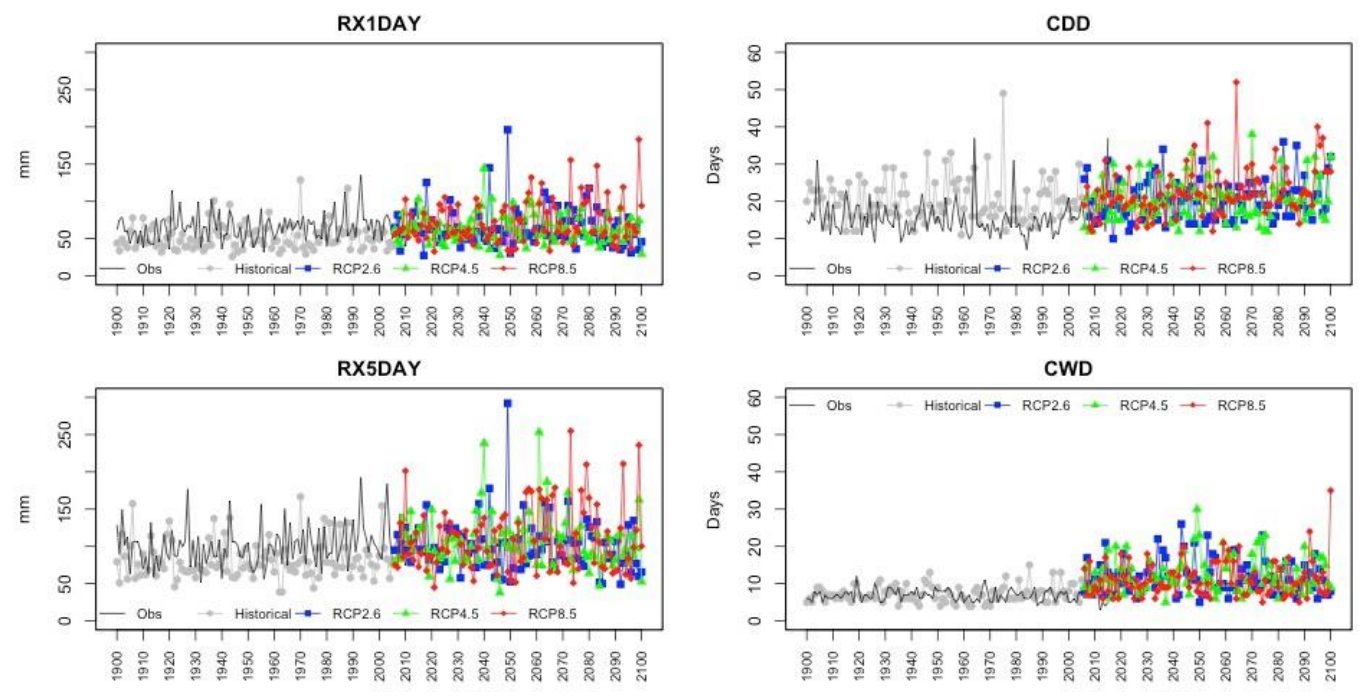

Figure 14 - Indexes of extreme events of precipitation calculated based on observed and simulated data (projected by IPSL(CM5MR)) for 1901 to 2100 . The indexes calculated are maximum value of rainfall in one (RX1DAY) and five days (RX5DAY) and consecutive dry (CDD) and wet days (CWD). The simulated data includes historical simulation (grey) and RCP2.6 (blue), RCP4.5 (green) and RCP8.5 (red).

RX1DAY index was underestimated by the historical simulation. The projected scenarios presents the increase of frequency of extreme events of precipitation in one day, mostly in RCP2.6 and RCP8.5 scenarios. Same pattern is presented for the RX5DAY index, which underestimate the observed data. This index presents also presents a tendency of occurrence of high values of RX5DAY. The highest value is simulated by the RCP2.6 simulation. CDD index calculated by historical projection overestimate the index calculated with observed data. Projections also shows the occurrence of extreme events with high values of CDD. CWD index is also expected to be higher on future, considering all scenarios of climate projections.

From the Figure 15 and the indexes of extreme events of temperature, it is noticed again the tendency of increase of temperature on future. The projections indicates that the maximum values of maximum and minimum temperature may increase until 2100 . Thus, the minimum value of maximum and minimum temperature shows the same trend.

An interest point is related to the SU, ID and FD indexes. SU was well simulated in historical projection when compared to the observed simulation. However, in future scenarios the projections shows increase of summer days. Although the model has good capacity in simulate the weather in the study region, the index DTR was largely underestimated by the model. 


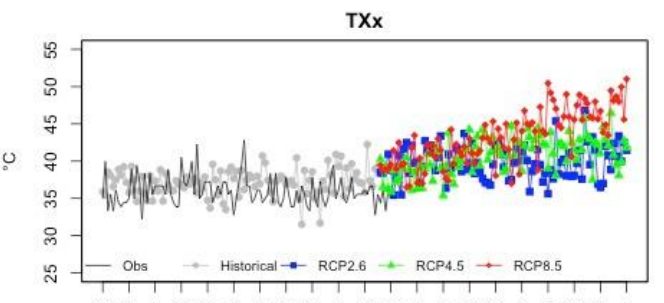

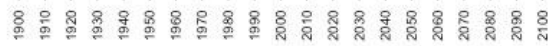

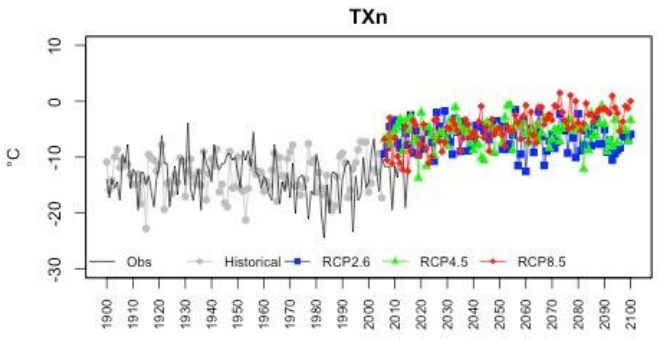

su

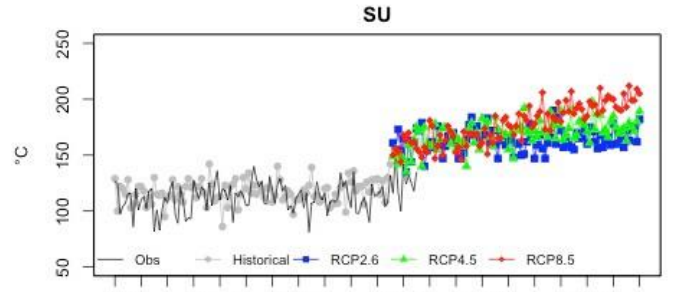

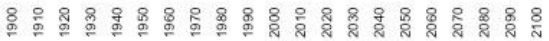
DTR

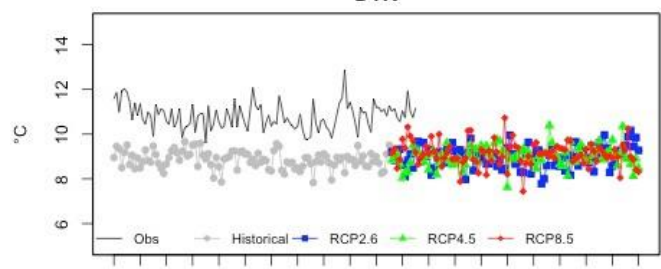

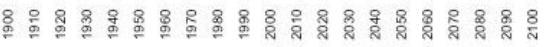

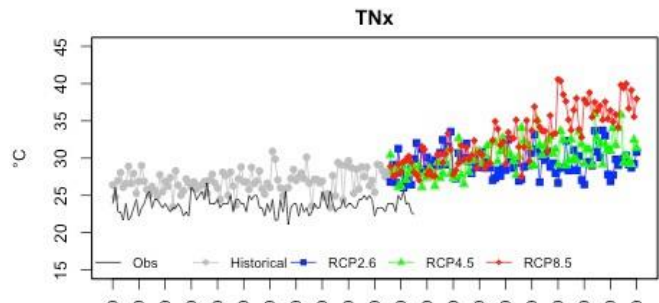

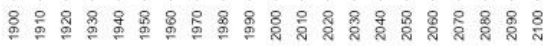

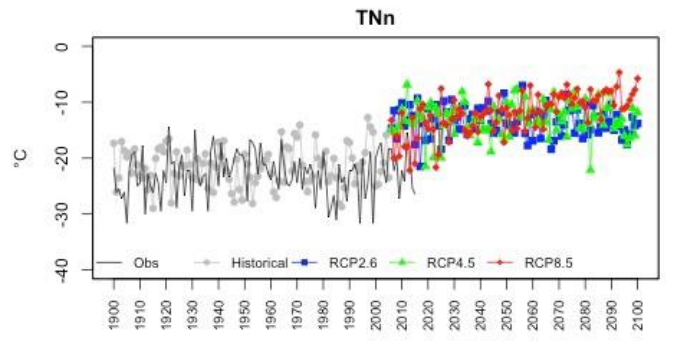

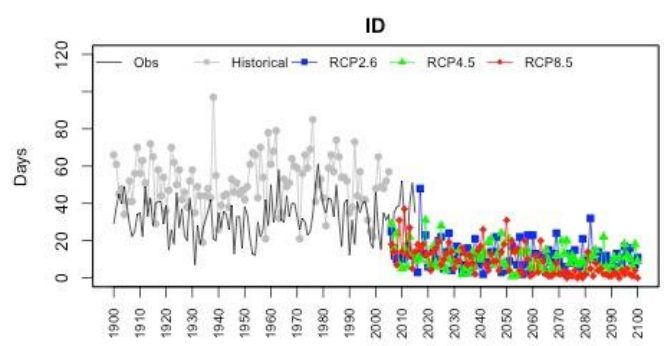

FD

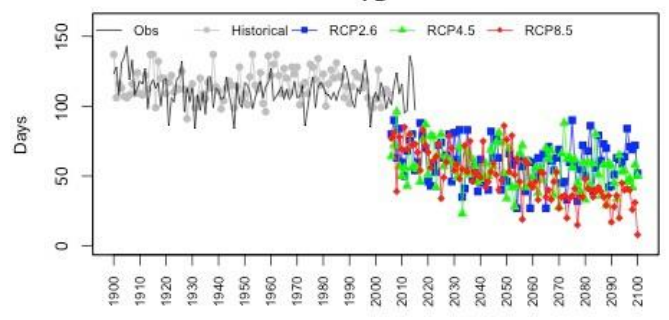

Figure 15 - Indexes of extreme events of temperature calculated based on observed and simulated data (projected by IPSL(CM5MR)) for 1901 to 2100. The index are maximum value of maximum (TXX) and minimum temperature (TNX), minimum value of maximum (TXn) and minimum temperature (TNn), summer days (SU), icing days (ID), daily temperature range (DTR) and frozing days (FD). The simulated data includes historical simulation (grey) and RCP2.6 (blue), RCP4.5 (green) and RCP8.5 (red).

\section{CONCLUSIONS}

In this part of the research it was identified the climate change in the region (from 1901 to 2015). By defining the occurrence of changes in patterns in the climatology and also in the occurrence of extreme events the authors believe that more researches need to be done about the climate change subject in order to define the local effect of climate change in different sectors. We 
believe that is important to apply this knowledge in specific areas, so it is possible to create mitigation measures, according to the forecast.

The model IPSL(CM5MR) was founded as the most accurate for the analyzed region. The model presented tendency of underestimation of precipitation and average and maximum temperature between 1901 to 2005 . Regarding to minimum temperature this models has tendency to overestimation.

Regarding to the indexes of extreme events, we noticed that most of them showed good performance. The model shows tendency of increasing of precipitation and increase of occurrence of extreme events, mostly of accumulated precipitation in one and 5 days. Consecutive wet days also may increase. It is also noticed decreasing of number of frost days and icing day and increasing of number of summer days.

\section{REFERENCES}

BASISTHA, Ashoke; ARYA, D. S.; GOEL, N. K. Spatial distribution of rainfall in Indian Himalayas-a case study of Uttarakhand region. Water Resources Management, v. 22, n. 10, p. 1325-1346, 2008.

CARVALHEIRO, Luis C. et al. Validação da Temperatura da Superfície do Mar a partir de medições de satélite. 2008.

CARVALHO, Leila MV; JONES, Charles; LIEBMANN, Brant. The South Atlantic convergence zone: Intensity, form, persistence, and relationships with intraseasonal to interannual activity and extreme rainfall. Journal of Climate, $v$. 17, n. 1, p. 88-108, 2004.

DALY, Christopher et al. A knowledge-based approach to the statistical mapping of climate. Climate research, v. 22, n. 2, p. 99-113, 2002.

FRICH, P. et al. Observed coherent changes in climatic extremes during the second half of the twentieth century. Climate research, v. 19, n. 3, p. 193-212, 2002.

GREEN, Timothy $R$. et al. Beneath the surface of global change: Impacts of climate change on groundwater. Journal of Hydrology, v. 405, n. 3, p. 532-560, 2011.

GROISMAN, Pavel Ya et al. Trends in intense precipitation in the climate record. Journal of climate, v. 18, n. 9, p. 1326-1350, 2005.

HANDLER, Paul. Possible association between the climatic effects of stratospheric aerosols and corn yields in the United States. Agricultural and forest meteorology, v. 35, n. 1-4, p. 205-228, 1985.

HANSEN, James et al. A closer look at United States and global surface temperature change. Journal of Geophysical Research: Atmospheres, v. 106, n. D20, p. 23947-23963, 2001.

HAYLOCK, Malcolm R. et al. Trends in total and extreme South American rainfall in 1960-2000 and links with sea surface temperature. Journal of climate, v. 19, n. 8, p. 1490-1512, 2006.

KALNAY, Eugenia; CAI, Ming. Impact of urbanization and land-use change on climate. Nature, v. 423, n. 6939, p. 528-531, 2003. 
KAZMIERCZAK, Bartosz; KOTOWSKI, Andrzej; WDOWIKOWSKI, Marcin. Trend analysis of annual and seasonal precipitation amounts in the Upper Odra catchment. Ochrona Srodowiska, v. 36, n. 3, p. 49-54, 2014.

KHARIN, Viatcheslav V. et al. Changes in temperature and precipitation extremes in the CMIP5 ensemble. Climatic change, v. 119, n. 2, p. 345-357, 2013.

MARENGO, Jose A.; VALVERDE, Maria C. Caracterização do clima no Século XX e Cenário de Mudanças de clima para o Brasil no Século XXI usando os modelos do IPCC-AR4. Revista Multiciência, v. 8, p. 5-28, 2007.

MOSS, Richard $\mathrm{H}$. et al. The next generation of scenarios for climate change research and assessment. Nature, v. 463, n. 7282, p. 747-756, 2010.

NEW, Mark et al. Precipitation measurements and trends in the twentieth century. International journal of climatology, v. 21, n. 15, p. 1889-1922, 2001.

NIELSEN, D. R.; BIGGAR, J. W. Miscible displacement in soils: I. Experimental information. Soil Science Society of America Journal, v. 25, n. 1, p. 1-5, 1961.

NOBRE, Carlos A. et al. Vulnerabilidades das megacidades brasileiras às mudanças climáticas: Região Metropolitana de São Paulo. Embaixada Reino Unido, Rede Clima e Programa FAPESP em Mudanças Climáticas, 2010.

ROSENZWEIG, Cynthia et al. Climate change and the global harvest: potential impacts of the greenhouse effect on agriculture. Oxford University Press, 1998.

SAGHAFIAN, Bahram; BONDARABADI, Sima Rahimi. Validity of regional rainfall spatial distribution methods in mountainous areas. Journal of Hydrologic Engineering, v. 13, n. 7, p. 531-540, 2008.

SALATI, E.; SANTOS, AA dos; NOBRE, C. As mudanças climáticas globais e seus efeitos nos ecossistemas brasileiros. Available in: http://www. comciencia. br/report agens/clima/clima14. htm, v. 2, 2004.

SILLMANN, J. et al. Climate extremes indices in the CMIP5 multimodel ensemble: Part 2. Future climate projections. Journal of Geophysical Research: Atmospheres, v. 118, n. 6, p. 2473-2493, 2013.

SOLOMON, Susan (Ed.). Climate change 2007-the physical science basis: Working group I contribution to the fourth assessment report of the IPCC. Cambridge University Press, 2007.

STOCKER, Thomas (Ed.). Climate change 2013: the physical science basis: Working Group I contribution to the Fifth assessment report of the Intergovernmental Panel on Climate Change. Cambridge University Press, 2014.

STONE, R. J. Improved statistical procedure for the evaluation of solar radiation estimation models. Solar energy, v. 51, n. 4, p. 289-291, 1993.

TEGEN, Ina et al. Towards a global aerosol climatology: preliminary trends in tropospheric aerosol amounts and corresponding impact on radiative forcing between 1950 and 1990. 1999.

THOMAS, Chris D. et al. Extinction risk from climate change. Nature, v. 427, n. 6970, p. 145-148, 2004. 
WEI, Hong; LI, Jian-Long; LIANG, Tian-Gang. Study on the estimation of precipitation resources for rainwater harvesting agriculture in semi-arid land of China. Agricultural Water Management, v. 71, n. 1, p. 33-45, 2005.

ZHOU, Botao et al. Projected changes in temperature and precipitation extremes in China by the CMIP5 multimodel ensembles. Journal of Climate, v. 27, n. 17, p. $6591-6611,2014$ 